\title{
COMPARING GOVERNMENT PERFORMANCE INDICATORS: A FUZZY-SET ANALYSIS
}

\author{
Phil KIM $^{a}$, Tobin IM ${ }^{b *}$ \\ ${ }^{a}$ Seoul National University, South Korea \\ ${ }^{b}$ Seoul National University, South Korea
}

\begin{abstract}
National governments rely on global performance indicators to grasp the current status and to build future strategies. However, no previous study has investigated pathways to government performance in terms of various indices empirically. With five possible determinants that are trait competitiveness, change-oriented citizenship behavior (CO-OCB), public service motivation (PSM), organizational identification (OI), and corruption tolerance, we try to find sufficient configurations to three representative government performance indicators which are "Government Effectiveness" (WGI), "Government Efficiency" (GCI), and "Throughput" (GC). The results indicate that three performance indicators are distinguished from one another with regard to the number of contributing factors to sufficient configurations, the role of "innovation-inclined" factors, and the role of corruption tolerance.
\end{abstract}

KEYWORDS: Government Performance, Performance Indicators, Fuzzy-set Analysis

\section{INTRODUCTION}

With amplified globalization taking place, countries tend to compete with each other more fiercely. In the pursuit of higher competitiveness, improving government performance has been an important issue in the discipline public administration. Thus, in a line with the domestic application of performance management system that is inspired by the "New Public Management" approach, international performance comparison has been receiving increasing attention from practitioners as well as academics. In this regard, many global institutions have elaborated various indices to measure government performance during the recent decades. National governments pay attention to their ranking fluctuations of such indices, "Government Effectiveness" from Worldwide Governance Indicators (WGI), "Government Efficiency" from Global Competitiveness Index (GCI), "Throughput" from Government Competitiveness (GC), "Government Efficiency" from World Competitiveness Scoreboard (WCS), and "Quality of Government (QoG)" from QoG Institute for instances.

Yet indicators for government performance are based on multiple perspectives that result in different rankings for one national government. This is mainly due to the varying understandings of the government's role that affect to definition of performance. "Government Efficiency" from GCI and WCS are based on Michael Porter's diamond model which defines government's role as "acting as a catalyst and challenger; it is to encourage - or even push - companies to raise their aspirations and move to higher levels of competitive performance" (Porter 1990). On the other hand, "Throughput" is specifically addressed as the core engine of "Government Competitiveness" that is defined as "the power of government, in light of various constraints, to take resource from inside and outside of the country, for the purpose of improving social, economic and cultural conditions of

\footnotetext{
${ }^{*}$ Corresponding author. E-mail address: tobin@ snu.ac.kr
} 
the nation aimed at sustainably enhancing respective citizen's quality of life" (Ho \& Im 2012). From the standpoint of "Throughput", active engagement in social development can be counted as government performance while supporters of "Government Efficiency" may not agree with it.

Concerning the issue, the construction of government performance indices is an increasingly hotdebated topic in academia (Ko \& Park 2012; Cho et al. 2013; Im et al. 2015) but any empirical study on varying emphasis of each indicator has not yet left an imprint on previous literature. Questions remain, how can a government perform better in terms of pubic management? And how can these performance indices be distinguished from each other with regard to managerial emphasis? Noticing this gap in the existing literature, we investigate organizational determinants of government performance scores with organizational behavioral factors, which are trait competitiveness, change-oriented citizenship behavior (CO-OCB), public service motivation (PSM), organizational identification (OI), and corruption tolerance. The explaining variables are popularly applied measures when analyzing pathways to organizational performance. Variables are collected from 2017 Government Competitiveness Global Survey and employee's survey scores are averaged to obtain a score for the country unit. We choose three-year average scores of "Government Effectiveness" (WGI), "Government Efficiency" (GCI) and "Through-put" (GC) as our dependent variables to compare with one another. As a method, we use fuzzy-set qualitative analysis (FsQCA) which is suitable to find necessary and sufficient conditions for outcome.

We limit our scale of analysis to developing nations, distinguished by membership of OECD, because analyzing which organizational antecedents have positive effects on performance has to be of special interest to them. In most developing countries, the administrational power that is capable for development only exist within the central government (Im 2017). Moreover, the national government's performance has a more direct impact on society than that of developed nations (Im 2016; 2017). Also, it should be noted that we do not discuss the theoretical arguments on constructs of indices further because our interest lies on which combination of organizational behavioral factors contribute to each performance score. We try to determine each indicator's own inherent emphasis on government's role by empirically investigating sufficient conditions rather than by approaching it theoretically.

The remainder of this chapter is divided into several parts. First, we thoroughly examine previous studies on government performance and its five antecedents. In this part, we discuss the public administrative context of each of these constructs and then we examine their impact on government performance, in both positive and negative ways. The next part includes an introduction of data that we derive from our dependent and independent variables from and FsQCA as analyzing method with its appropriateness on our study. Finally, we describe the results from the empirical analysis followed by a wrapping up conclusion which further explains the potential implications of different sufficient conditions for government performance indicators.

\section{LITERATURE REVIEW}

\subsection{Government Performance}

Recent attempts to administrational reforms and many corresponding managerial concepts to make innovations successful are mostly related to increasing government performance (Coggburn \& Schneider 2003). Performance management has been applied to governments across the world and a considerable amount of research is conducted on the antecedents of strong performance $(\mathrm{O}$ ' Toole 2000; Ingraham \& Donahue 2000). Despite the vast amount of literature focusing on public management and its impact on government performance, the exact concept of performance remains inconclusive.

In this regard, New Public Management has focused on developing a performance measurement system like Program Assessment Rating Tool (PART) in the U.S. However, Trivedi (2017) pointed out that even though performance of a country's government is a key determinant to competitiveness of nations, the quality and appropriateness of performance measurement is still in vague. Measurement of performance within a country is important but comparable indicators are 
needed also to understand the competitiveness of a nation. Thus, international indices that intend to measure government performance need to be considered.

There are several international institutions that measure governments' performance at country level every year. The World Bank, the World Economic Forum, the Government Competitive-ness Center, Quality of Government, International Institute for Management Development (IMD) and the World Justice Project are the most well-known examples. "Government Effectiveness" captures perceptions of the quality of public services, the quality of the civil service and the degree of its independence from political pressures, the quality of policy formulation and implementation, and the credibility of the government's commitment to such policies (The Worldwide Governance Indicators 2018). "Government Efficiency" is measured including indicators of wastefulness of government spending, burden of regulation and transparency of policymaking (World Economic Forum 2018). "Throughput", as one of stages in Easton's system theory, is composed of human capacity and management capacity of a government which reflects the current status and future potential growth of its competitiveness (Government Competitiveness Center 2018). "Quality of Government" deals as sub-category with almost 70 indicators to address the questions of how to create and maintain high quality government institutions (Quality of Government 2018). IMD publishes "World Competitiveness Scoreboard" that deal with country's capacity to create desirable environment for doing business and "Government Efficiency" as sub-indicator to measure government performance. The World Justice Project measures "Constraints on Government Powers" and "Open Government" which reflect to what extent government is ruling by law (World Justice Project 2018). Due to varying ability to deal with different policy problems, national governments refer to those indicators to recognize current status. As it can be seen in abovementioned descriptions of indices, each differs from one another in its core assumption of performance. In the light of existing multiple performance indicators, we try to compare which aspects have been empathized by each index.

Hypothesis 1: Each government performance indicator has different sufficient conditions for higher score.

\subsection{Five Critical Factors to Government Performance}

\section{(1) Trait Competitiveness}

Trait competitiveness deals with how a person reacts to the social comparison to others and related resource distribution of society (In 2017). When faced with competitive situations, individuals respond differently; some dive into the competition and enjoy it, while others try not to get into such situations at all. Whether competition motivates people or not largely correlates with the trait of competitiveness, of which characteristics are generally applicable, stable over time, and rarely show sudden changes or discontinuities (Connelly et al. 2014; Mudrack et al. 2012). Newby \& Klein (2014) has categorized factors of trait competitiveness into four classifications which are general competitiveness, dominance, competitive effectivity and personal enhancement.

As is a relatively new term, the literature on trait competitiveness in specific has just been burgeoning based on research using similar concepts that have constantly been accumulated from the past. Studies on trait competitiveness can be traced back to concepts such as competitive instincts, mental attitude during performance, and an intense desire to win, which were introduced by Triplett in 1897 . Researchers have sought to determine multiple dimensions of competitiveness with applicable measurements (Houston et al. 2002; Newby \& Klein 2014). In contrast to early studies of trait competitiveness, in which scholars tend to emphasize the side of perceiving others as targets of comparison, recent work has proposed a new dimension of comparison that is personal development competitiveness (In 2017; Choi 2017; Choi \& Jung \& Im 2018). Personal development competitiveness focus on individual's self-satisfaction based on assumption that feeling of fulfillment would follow when standards made by oneself are achieved. 
The relationship between trait competitiveness and organizational performance has not yet been determined. However, as trait competitiveness is defined as "desire to win" or "desire to perform well" (Franken \& Brown 1995) and "competing to win" or "competing to excel" (Hibbard \& Buhrmester 2010), it seems natural to connect these attributes to performance. The impact of trait competitiveness on variables related to organizational performance has been argued in different ways. For instance, it can affect intrinsic job motivation in either positive way (Epstein \& Harackiewicz 1992; Choi 2017) and negative way (Deci et al. 1981; Vallerand \& Gauvin \& Halliwell 1986; Amabile 1982). Even though these sub-dimensions are not considered in this study, personal development competitiveness is reported to decrease corruption tolerance, while interpersonal competitiveness showed the opposite effect, moderated by performance-oriented climate (Mudrak et al. 2012; Choi \& Jung \& Im 2018)

\section{(2) Change-oriented Organizational Citizenship Behavior}

Change-oriented Organizational Citizenship Behavior (CO-OCB) can be defined as "constructive, extra-role efforts by individual retail boundary-spanning employees to identify and implement organizationally functional changes with respect to work methods, policies, and procedures within the context of their jobs, stores, or organizations" (Bettencourt 2004:165). CO-OCB reflects one distinctive dimension of organizational citizenship behavior (OCB), which is individual initiative It is the only challenging type compared to other six affiliative types of dimensions which are helping, sportsmanship, organizational loyalty, compliance, civic virtue, self-development (Podsakoff et al 2000; Choi 2007). Employees engaging in CO-OCB have the tendency to improve organizational functioning by rearranging inefficient working mechanisms (Campbell 2016; Bettencourt 2004; Morrison \& Phelps 1999). This might conflict with the existing coordination of work processes, and even established interpersonal networks. However, CO-OCB shares a common trait with other citizenship behavior in terms of voluntariness because formal job description and official performance indicators hardly ever cover behavior of employees driven by CO-OCB.

Despite the fact that the concept of CO-OCB has gained considerable attention in business management in terms of innovation, this concept has not been much discussed within public administration area (Campbell 2015; 2016). This can partly be explained with varying perspectives for administration's role. The traditional politics administration dichotomy argues that the public administration employees' role is limited to implementing the politician's will. Yet it is plausible that the public sector also needs members' change-oriented behavior regarding major critics bureaucracy is facing, including prevalent buck-passing culture, red tape, and unbendable procedures. CO-OCB may help public employees to perform beyond the citizen's expectations so as to provide satisfactory public service (Vigoda-Gabot \& Beeri 2012).

With regard to government performance, CO-OCB may play a major role in both positive and negative ways. First, it can be seen as a catalyst to transform bureaucratic structures of public organizations into a more creative configuration (Bernier \& Hafsi 2007). To elaborate, CO-OCB boosts extra-role behavior by employees, who do not expect recognition nor rewards, that leads to better performance for the whole organization. However, it is also possible that by making voice to change organizational status-quo, CO-OCB may create controversy on which procedure is more correct. It should be noted that $\mathrm{CO}-\mathrm{OCB}$ driven behavior has the potential to cause some unnecessary confusion that might interfere with performance.

\section{(3) Public Service Motivation}

Public service motivation (PSM) can be understood as "an individual's predisposition to respond to motives grounded primarily or uniquely in public institutions and organizations" (Perry \& Wise 1990:368). The theory is based on three core assumptions; individuals with PSM seek for membership in public organization; PSM is positively related to individual performance; and organization with PSM oriented members are less dependent on monetary rewards (Perry \& Wise 1990:370-371). PSM has become an emerging topic in the field of public administration during last three decades, since this concept provides insights into public organizational phenomenon in 
specific with important practical implications regarding limited utilitarian incentives compared to that of private sector. In contrast to rational choice theories which assume that individuals are selfinterest seekers, PSM theory proposes morally and socially motivated individuals who are willing to engage in producing public goods (Neumann \& Ritz 2015).

Empirical studies on the impact of PSM on job performance have shown conflicting results. Naff and Crum (1999), using nearly 10,000 samples of the U.S federal employees' data, found a significant relationship between PSM and self-reported performance. Alonso and Lewis (2001) used two measures of merits to test the impact of PSM but the results varied according to the year of the data the researchers used. Bright (2007) determined whether Person-Organization Fit (P-O Fit) mediates the relationship using 205 samples but only found direct effect of PSM on job performance. Vandenabeele (2009) found evidence confirming that Belgian civil servants with high PSM have better performance results. This relationship was also supported by a case of Chinese public organization, which used supervisor-rated performance data and employee-rated PSM to enhance robustness (Miao et al. 2018). Schott et al (2015) argued that these inconclusive findings may partially result from the fact that the identity perspective was not considered, which explains role-based differences driven by varying individual understandings of the meaning of serving the public.

(4) Organizational Identification

Organizational identification (OI) is a construct that arose from work on social identity theory (Ashforth \& Mael 1989) and can be defined as the "perception of oneness with or belongingness to an organization" (Mael \& Ashforth 1992). OI makes individuals categorize themselves as members of their employing organizations and promotes positive responses toward directions from higherups. Thus, members with high OI willingly invest more time for their organization. This effort leads not only to better individual performances but also contributes to the organizational success.

A vast amount of literature on OI exists, in spite of the fact that the unique construct OI has been receiving attention only during recent decades (Ashforth \& Mael 1989) and considering that the first detailed model was proposed a long time ago (March \& Simon 1958). While most studies focus on the role of OI bringing beneficial outcomes to organizations (Likert 1967; Mael \& Ashforth 1992; Pratt 1998), a considerable number of papers state the opposite effect. For instance, Dutton \& Dukerich (1991) found evidence indicating that strong OI is leading to stress and depression of employees. Umphress et al. (2010) reported that identified employees may facilitate unethical behaviors within organization. Even though it was non-significant, Brown (1969) showed relationship between OI and group cohesiveness is negative.

According to previous research, the impact of OI on organizational performance can be explained in two ways. Generally, OI has been put in relation to better organizational outcomes (Lee et al. 2015). However, recent studies point out a possible link between OI and lower performance. Specifically, OI may be helpful for routine and noncreative tasks, while it can become a hindrance for innovative assignments (Chen 2011). Hekman et al. (2016) argue that because members with strong OI tend to show appropriate behavior within the organization, it might harm performance when the task calls for more creativity. Veltrop et al. (2016) discussed how OI moderates the relationship between tenure and task involvement in a negative way.

\section{(5) Corruption Tolerance}

Corruption occurs when one violates the norms of institutions for one's self-interest. In terms of public organization, a corrupt act refers to undesirable use of power by public employees whose job is related to a certain benefit induced by the act, both in direct and indirect ways (Im 2018). In this chapter, corruption tolerance is defined as public employees' perception of the acceptable extent of government corruption. As government corruption is known to harm public goods, distorting resource distribution, prevalent corruption may ultimately hinder the national competitiveness (Sandholz \& Koetzle 2000). 
Even though corruption generally impedes performance, since one's self-interest often contradicts with the organizational goal, some suggest that corruption may contribute to "greasing the wheel" (Neff 1964; Huntington 1968) exclusively in governments of developing countries. Specifically, these functionalists believe that corruption is likely to facilitate efficient procedure of bureaucracy by overcoming unnecessary red-tapes in developing countries. For example, when regulations are not optimal or are inefficient, corruption may function as a deregulating mechanism. Also, a corruption culture may enhance efficiency in the sense that bureaucrats in developing countries are likely to attracted to potential bribes, so-called "voluntary taxes" (Blackburn \& Forgues-Puccio 2007). Yet most scholars consider corruption as one of the most important obstacles for development, saying that abovementioned benefits of corruptions are rather exceptions than a confirming rule.

As is discussed in this part, each variable's relationship to performance seems to vary depending on certain conditions. Taking our first hypothesis into account, it seems natural to assume different performance definition will lead to different roles of factors for higher performance. Thus, our second hypothesis is as follows:

Hypothesis 2: Five factors' role to sufficiently cause higher government performance vary on each indicator.

\section{METHOD AND ANALYSIS}

\subsection{Data}

Our data on public employee's attributes and behaviors are collected through the 2017 Government Competitiveness Global Survey, which was conducted by the Government Competitiveness Center. The survey intended to explore public employees' perceptions on various organization behavioral factors including trait competition, CO-OCB, PSM, OI and corruption tolerance. (See the appendix for specifics). The survey was distributed via e-mail and was published on the Center for Government Competitiveness's homepage from the middle of June to late August in 2017. With use of pre-existing sample list of private survey company, Kantar Republic, the students of Global Master of Public Administration (GMPA) in Seoul National University, of whom most are high public officials in their own countries, participated in the survey and contributed to snowball sampling. The final sample size of public servants includes 482, covering 62 developing countries. The characteristics of the participants are described in Table 1. We use average scores to transform the unit from individual to organization as it is widely adopted method by many international survey construct such as World Values Survey and World Happiness Report. All independent variables went through factor analysis of which loaded for one single factor each.

Additionally, performance data was derived from three different research institutions, including the World Bank Group's Worldwide Governance Indicators (WGI), the World Economic Forum's Global Competitiveness Index (GCI), and the Government Competitiveness Center's Government Competitiveness (GC). Although other institutions like Quality of Government and The World Justice Project provide a robust index, measuring similar concepts of government performance, we set these indices aside judging that "quality" nor "rule of law" do not reflect effectiveness, efficiency nor competitiveness in specific.

Also we do not consider IMD's "Government Efficiency" despite its name falls into our category because it only covers 60 countries while its definition of competitiveness is similar to that of WEF, which covers over 140 countries (IMD 2014). Instead, we use sub-indicators, derived from the aforementioned three institutions, which are "Government effectiveness" from WGI, "Government Efficiency" from GCI, and "Throughput" from GC. It is noted that some data source of three indices overlap one another but each indicator can be identified with its originality. 


\section{Gender}

Female

Male

Region

Africa

Asia

Europe

Middle East Asia \& North Africa

South America
Table 1. Characteristics of Respondents

Job Position Level

$175(36.3 \%)$
$307(63.7 \%)$
$59(12.2 \%)$
$146(30.3 \%)$
$91(18.9 \%)$
$67(13.9 \%)$
$119(24.7 \%)$

$175(36.3 \%)$
$307(63.7 \%)$

$119(24.7 \%)$

$\begin{array}{ll}\text { Upper } & 42(8.7 \%) \\ \text { Middle-high } & 133(27.6 \%) \\ \text { Middle } & 258(53.5 \%) \\ \text { Entry } & 49(10.2 \%) \\ \text { Age } & \\ 18-29 & 95(19.7 \%) \\ 30-39 & 196(40.7 \%) \\ 40-49 & 111(23.0 \%) \\ 50 \text { or older } & 80(16.6 \%)\end{array}$

Total Obs.

$482(100 \%)$

\subsection{Methods}

To verify, how the aforementioned five factors affect government performance, we have utilized the method of fuzzy-set qualitative comparative analysis (FsQCA). FsQCA is an increasingly popular set-theoretic strategy that researchers in various fields have started to use (Ragin 1987; 2000). FsQCA can be distinguished from general quantitative analysis with the fact that it employs the traditional Boolean logic to determine complex causality of set of variables rather than estimating the net effects of single variables (Longest \& Vaisey 2008). At the same time, FsQCA offsets traditional criticism on subjectivity of qualitative analysis in the sense that it uses numeric scores in analysis. Therefore, this method is particularly suitable to analyze a set of variables' complex causality in small-numbered case analyses.

In our study, the use of FsQCA is appropriate for two reasons. First, the number of observations in our dataset is limited. As FsQCA requires to drop any missing data to avoid misinterpretation (Ragin 2008), we excluded any observation that has missing data. This led to an even smaller number of cases. We conducted a FsQCA with 18 cases for WGI, 49 cases for GCI and 50 cases for GC. Second, we try to determine which combinations of certain individual's attributes and organizational behavior decide higher government performance. By analyzing sufficient conditions of three indices, we aimed to not only identify which factors contribute to government performance but also to investigate which aspects are more emphasized in each indicator.

The process of FsQCA is as follows. First, the outcome variable needs to be constructed with fuzzyset calibration. Calibration refers to categorizing countries' governments into groups with fuzzy-set value which range from full membership (1) to non-membership (0). This membership score reflects the degrees to which governments are included in or out of sets (Ragin 2008). After calibration, a case that has a threshold value (0.5) is excluded from the final analysis because it is neither in nor out of sets. In this regard, we first normalized three indices, WGI, GCI and GC, then calibrated them with the threshold value of 0.5 (Paykani \& Rafiey \& Sajjadi 2018). Also, we set fully-in cases to have a value exceeding ' 0.95 ', whereas fully-out cases to have value less then '0.05' (Ragin 2000). Second, the independent variables need to be calibrated as well. We applied the same method to five explaining variables. As is dependent variable, a threshold value of 0.5 has been chosen due to the reason that there are not many theories on precisely deciding the exact standard of those variables. As such, we defined two fuzzy-sets for each variable, governments with high-PSM employees and governments with low-PSM employees for instance. Each government has its fuzzy-score which represents its partial membership to the set. Finally, with these calibrated variables, we constructed the truth table that illustrates, which configuration of antecedent conditions the case meets (Fiss 2011). In our case, since we have five possible antecedents, the number of row in truth table would be 32 (i.e. $2^{\wedge} 5$ ) which represents all possible combinations. By reducing the number of rows in the table with an algorithm using Boolean algebra, we determined 
which combinations of factors are considered sufficient to explain outcome of three indices. We used STATA 13 program to perform the whole process.

Table 2. Descriptive Statistics

\begin{tabular}{lllllllll}
\hline & $\begin{array}{l}\text { Competiven } \\
\text { ess }\end{array}$ & CO-OCB & PSM & OI & Corruption & $\begin{array}{l}\text { Government } \\
\text { Effectivenes } \\
\text { (WGI }\end{array}$ & $\begin{array}{l}\text { Government } \\
\text { Efficiency } \\
\text { (GCI) }\end{array}$ & $\begin{array}{l}\text { Throughput } \\
\text { (GC) }\end{array}$ \\
\hline Mean & 4.17 & 4.33 & 4.22 & 4.18 & 2.66 & 0.37 & 3.43 & 0.5 \\
S.D. & 0.53 & 0.71 & 0.66 & 0.57 & 0.68 & 0.13 & 0.7 & 0.08 \\
Range & $2.80-5.01$ & $2.90-5.50$ & $2.88-5.80$ & $3.11-5.21$ & $1.68-4.00$ & $0.08-0.63$ & $1.49-5.56$ & $0.34-0.69$ \\
\hline
\end{tabular}

\subsection{Empirical Results}

In the following we briefly introduce the meaning of fuzzy-set outcome scores and explain the results with regard to necessary and sufficient conditions. There are two types of measurements to test explanation power of set relations: set-theoretic consistency and set-theoretic coverage. The consistency score represents the degree to which cases sharing antecedent conditions show the same outcome. Given that generally accepted level of consistency for the test of necessity is 0.9 (Schneider \& Schulze-Bentrop \& Paunescu 2010), we applied this standard to determine the meaningful conditions. On the other hand, an acceptable consistency score for sufficient condition is 0.75 or 0.8 (Ragin 2008). The coverage value reflects the empirical relevance of a solution. Given that multiple paths to outcome variable may exist, a coverage value can be low de-spite of high consistency score. There are three kinds of coverage, which are raw, unique and solution. The solution coverage evaluates the complete level to which a combination accounts for instances of an outcome. Raw coverage refers to each term of the solution while unique coverage means each individual solution.

First, we respectively test necessary conditions for the fuzzy-sets of governments with high performance scores which are "Government Effectiveness" (WGI), "Government Efficiency" (GCI) and "Throughput" (GC). As it can be seen in Table 3, none of antecedent conditions match this standard. Yet it is noted that four attribution factors, competitiveness, CO-OCB, PSM and OI, are showing high consistency scores of which average scores are around 0.75, while scores of corruption tolerance are relatively low.

Table 3. Analysis of Necessary Conditions

\begin{tabular}{|c|c|c|c|c|c|}
\hline & Competitiveness & CO-OCB & PSM & OI & Corruption \\
\hline $\begin{array}{ll}\text { Government } & \text { Effectiveness } \\
\text { (WGI) } & \end{array}$ & 0.855 & 0.847 & 0.872 & 0.837 & 0.598 \\
\hline Government Efficiency (GCI) & 0.700 & 0.679 & 0.682 & 0.680 & 0.665 \\
\hline Throughput (GC) & 0.806 & 0.750 & 0.742 & 0.728 & 0.561 \\
\hline Average & 0.787 & 0.758 & 0.765 & 0.748 & 0.608 \\
\hline
\end{tabular}

For the next step, we explore which set of sufficient conditions lead governments to receive higher score for each indicator. Full circles $(\bullet)$ indicate the presence of a condition (i.e. governments fall into a set of high PSM) and empty circles $(\bigcirc)$ indicate the absence of it (i.e. governments fall into a set of low PSM). Blank cells indicate ambiguous conditions. We set the consistency value at 0.75 to test configurations of sufficient conditions. With the five possible variables for government performance, Table 4 shows varying results depending on each indicator. This proves our hypothesis that each government performance indicator has different sufficient conditions for higher score.

"Government Effectiveness" (WGI) has two sets of sufficient conditions of which all five variables have their own role to contribute. Lower trait competitiveness and lower corruption tolerance with higher $\mathrm{CO}-\mathrm{OCB}$, higher PSM, higher OI are likely to create better performance. In the second 
configuration, the role of trait competitiveness replaces that of CO-OCB. Corruption tolerance keeps playing a negative role in both set relations while PSM and OI constantly show the opposite effect. In the same time, the role of trait competitiveness and CO-OCB are not conclusive. The consistency score is set over 0.8 for both cases and the total solution consistency is over 0.9 . The total coverage is less than 0.5 .

"Government Efficiency" (GCI) also has two configurations of sufficient conditions. The first configuration is very similar to that of Government Effectiveness (WGI) except for the ambiguous role of PSM. In the second configuration, it is notable that higher corruption tolerance combined with higher trait competitiveness, higher PSM, and higher OI can lead to higher performance. As discussed in literature review, corruption tolerance is believed to have positive effects on economic development in the third world under certain conditions. It should be noted that the unique coverage of the second configuration is almost two times higher than that of the first one. The consistency scores are over 0.8 for both set combinations. The total coverage and solution consistency are in the same level as those of "Government Effectiveness" (WGI).

"Throughput" (GC) has three configurations of sufficient conditions which are much simpler compared to "Government Efficiency" and "Government Effectiveness". Higher PSM combined with lower OI and lower corruption tolerance are sufficient conditions to cause better performance. Additionally, higher CO-OCB with lower OI can lead to higher "Throughput" score. It can be noted that the role of OI differs from other indicators. In our third configuration, higher competitiveness solely has raw coverage of 0.806 to the outcome which is even higher than total coverage of other indicators. However, combination of presence of PSM and absence of OI and corruption tolerance show higher consistency than competitiveness as sole determinant. The total coverage is almost double to other indicators whereas solution consistency is the lowest.

Table 4. Sufficient Configurations of Antecedent Conditions for Government Performance

\begin{tabular}{|c|c|c|c|c|c|c|c|c|}
\hline \multirow{2}{*}{ Indicator } & \multicolumn{5}{|c|}{ Antecedent Conditions } & \multirow{2}{*}{$\begin{array}{l}\text { Raw } \\
\text { coverage }\end{array}$} & \multirow{2}{*}{$\begin{array}{l}\text { Unique } \\
\text { coverage }\end{array}$} & \multirow{2}{*}{ Consistency } \\
\hline & Competitiveness & $\mathrm{CO}-\mathrm{OCB}$ & PSM & OI & Corruption & & & \\
\hline \multirow{3}{*}{$\begin{array}{c}\text { Government } \\
\text { Effectiveness } \\
\text { (WGI) }\end{array}$} & 0 & $\bullet$ & $\bullet$ & - & 0 & 0.355 & 0.039 & 0.893 \\
\hline & $\bullet$ & 0 & $\bullet$ & $\bullet$ & 0 & 0.401 & 0.084 & 0.904 \\
\hline & & & & & & \multicolumn{3}{|c|}{$\begin{array}{r}\text { Total coverage: } 0.439 \\
\text { Solution consistency: } 0.911\end{array}$} \\
\hline \multirow{3}{*}{$\begin{array}{l}\text { Government } \\
\text { Efficiency } \\
\text { (GCI) }\end{array}$} & $\bullet$ & 0 & & $\bullet$ & 0 & 0.345 & 0.061 & 0.868 \\
\hline & $\bullet$ & & $\bullet$ & $\bullet$ & $\bullet$ & 0.394 & 0.110 & 0.846 \\
\hline & & & & & & \multicolumn{3}{|c|}{$\begin{array}{r}\text { Total coverage: } 0.455 \\
\text { Solution consistency: } 0.845\end{array}$} \\
\hline \multirow{3}{*}{$\begin{array}{l}\text { Throughput } \\
\text { (GC) }\end{array}$} & & & $\bullet$ & $\bigcirc$ & $\bigcirc$ & 0.427 & 0.002 & 0.893 \\
\hline & & $\bullet$ & & $\bigcirc$ & & 0.439 & 0.007 & 0.868 \\
\hline & $\bullet$ & & & & & 0.806 & 0.339 & 0.806 \\
\hline
\end{tabular}

Total coverage: 0.821

Solution consistency: 0.786

\section{CONCLUSION}

Governments of developing countries rely on performance indicators produced by several global institutions to estimate current status and to decide how and where to invest their limited resource. Understanding the different determinants of various performance indicators would help governments to manage their distribution of attention. Discussing public employees' attributional 
and behavior factors as sufficient conditions is also helpful as one of most important performance strategies concerns to how to manage human resource in public organizations.

Aiming at a better understanding of which factors lead to higher government performance scores and how these scores vary in relation to sufficient conditions, this study investigates relationship between three well-known performance indicators ("Government Effectiveness" (WGI), "Government Efficiency" (GCI), "Throughput" (GC)) and five critical factors (Trait Competitiveness, CO-OCB, PSM, OI, Corruption Tolerance) with the use of FsQCA method. We verify our two hypotheses that each performance indicators have different emphasis with regard to sets of sufficient antecedents $(\mathrm{H} 1)$ and that each attributional factor has different roles within respective score $(\mathrm{H} 2)$. The findings of this paper have several interesting points.

First, the number of attributional factors included in causal recipes varies on three performance indices. For instance, all five attributional factors, trait competitiveness, CO-OCB, PSM, OI, corruption tolerance, have their own contribution to the "Government Effectiveness" (WGI) score. Nonetheless, "Throughput" (GC) has the simplest sufficient condition sets which include trait competitiveness as a sole determinant with raw coverage and a consistency score of 0.806 . It needs to be noted that Government Competitiveness Center has underlined the importance of this trait for years even though the results of the 2017 Government Competitiveness Global Survey are not included as sub-indicators yet.

Second, combined with other factors, "innovation-inclined" attributional factors such as trait competitiveness and CO-OCB show negative or inconclusive contribution to "Government Effectiveness" (WGI) and "Government Efficiency" (GCI) while it is not the case for "Throughput" (GC). Trait competitiveness deals with winning strategy with active engagement (In 2017). Also, CO-OCB is known for its innovative characteristic and its support to creative organizations (Vigoda-Gabot \& Beeri 2012; Bernier \& Hafsi 2007). Therefore, this deviation concerning roles of "innovation-inclined" attributional factors can be partially explained by the perception of the task of government to be centered more on implementation of policy rather than determination of policy in Government Effectiveness (WGI) and Government Efficiency (GCI).

Finally, it is notable that only "Government Efficiency" (GCI) has sufficient configurations with the positive role of corruption tolerance. It is believed that corruption may have a positive impact on economic development in the developing countries under certain conditions (Neff 1964; Huntington 1968). To further explain, despite of well-accepted detrimental effects of corruption, some scholars argue that corruption may function as a deregulating mechanism as well as "voluntary taxes" that become incentive to drag human resource to public sector. In this regard, sufficient configuration with positive role of corruption tolerance can be explained by the fact that the "Government Efficiency" (GCI) puts a lot of emphasis on economic aspect while considering less the managerial contexts of public organizations (Han 2014; Im et al. 2015).

The limitations of study are as follows. First, even though the use of average score is a popularly applied method, it may distort the result concerning the unit of analysis. Also, we consider five attributional factors altogether because they are widely discussed antecedents for organizational performance of which researches have different model stages. Some scholars might think these factors should be argued in different stages. Lastly, although many fuzzy-set analysis approaches to effect of determinants respectively, FsQCA has an analytical advantage in its way of explaining sets of variables altogether to find pathways to outcome. Therefore, some may find our interpretation on individual antecedent less appropriate. Future research should attempt to obtain dataset collected at organizational level, to construct more sophisticated behavioral models, and explain further the inbetween relationship of explaining variables in one causal recipe.

\section{ACKNOWLEDGMENT}

This study was supported by a National Research Foundation of Korea Grant from the Korean Government (NRF-2017S1A3A2065838). 


\section{REFERENCES}

Alonso, P., \& Lewis, G. B. (2001). Public service motivation and job performance: Evidence from the federal sector. The American Review of Public Administration, 31(4), 363-380.

Amabile, T. M. (1982). Children's artistic creativity: Detrimental effects of competition in a field setting. Personality and Social Psychology Bulletin, 8(3), 573-578.

Ashforth, B. E., \& Mael, F. (1989). Social identity theory and the organization. Academy of management review, 14(1), 20-39.

Bernier, L., \& Hafsi, T. (2007). The changing nature of public entrepreneurship. Public Administration Review, 67(3), 488-503.

Bettencourt, L. A. (2004). Change-oriented organizational citizenship behaviors: The direct and moderating influence of goal orientation. Journal of Retailing, 80(3), 165-180.

Blackburn, K., \& Forgues-Puccio, G. F. (2007). Distribution and development in a model of misgovernance. European Economic Review, 51(6), 1534-1563.

Bright, L. (2007). Does person-organization fit mediate the relationship between public service motivation and the job performance of public employees?. Review of public personnel admin-istration, 27(4), 361-379.

Campbell, J. W. (2015). Identification and performance management: An assessment of changeoriented behavior in public organizations. Public Personnel Management, 44(1), 46-69.

Campbell, J. W., \& Im, T. (2016). PSM and turnover intention in public organizations: Does change-oriented organizational citizenship behavior play a role? Review of Public Personnel Administration, 36(4), 323-346.

Cho, W.H., Im, T., Jung, J.S., Lee, M.A., \& Cha, S.Y. et al. (2013). A Cross-County Comparison of Government Competitiveness: Measures and Evaluation. Korean Comparative Government Review, 17(2), 95-124.

Coggburn, J. D., \& Schneider, S. K. (2003). The relationship between state government performance and state quality of life. International Journal of Public Administration, 26(12), 1337-1354.

Connelly, B. L., Tihanyi, L., Crook, T. R., \& Gangloff, K. A. (2014). Tournament theory: Thirty years of contests and competitions. Journal of Management, 40(1), 16-47.

Deci, E. L., Schwartz, A. J., Sheinman, L., \& Ryan, R. M. (1981). An instrument to assess adults' orientations toward control versus autonomy with children: Reflections on intrinsic motivation and perceived competence. Journal of educational Psychology, 73(5), 642.

Dutton, J. E., \& Dukerich, J. M. (1991). Keeping an eye on the mirror: Image and identity in organizational adaptation. Academy of management journal, 34(3), 517-554.

Epstein, J. A., \& Harackiewicz, J. M. (1992). Winning is not enough: The effects of competition and achievement orientation on intrinsic interest. Personality and Social Psychology Bulletin, 18(2), 128-138.

Fiss, P. C. (2011). Building better causal theories: A fuzzy set approach to typologies in organization research. Academy of Management Journal, 54(2), 393-420.

Franken, R. E., \& Brown, D. J. (1995). Why do people like competition? The motivation for winning, putting forth effort, improving one's performance, performing well, being instrumental, and expressing forceful/aggressive behavior. Personality and individual differences, 19(2), 175-184.

Government Competitiveness Center. (2018). The Government Competitiveness Report. Seoul.

Han, B. H. (2014). Developing Measurement Index of Government Capacity and A Cross-Country Comparison: From Government Competitiveness Perspectives. Unpublished master's thesis, Seoul National University, Seoul, Korea.

Hekman, D. R., Steensma, H. K., Bigley, G. A., \& Hereford, J. F. (2009). Effects of organizational and professional identification on the relationship between administrators' social influence and professional employees' adoption of new work behavior. Journal of Applied Psychology, 94(5), 1325. 
Hibbard, D. R., \& Buhrmester, D. (2010). Competitiveness, gender, and adjustment among adolescents. Sex Roles, 63(5-6), 412-424.

Ho, A \& Im, T. (2012). Defining a New Concept of Government Competitiveness. Korean Journal of Public Administration. 50(3), 1-34

Houston, J., Harris, P., McIntire, S., \& Francis, D. (2002). Revising the competitiveness index using factor analysis. Psychological Reports, 90(1), 31-34.

Huntington, Samuel P. (1968). Political Order in Changing Societies. New Haven: Yale University Press.

Im, T et al. (2015). Government Competitiveness: Theory and evaluation index. Seoul: Pakyongsa.

Im, T et al. (2017). Comparative Administrative Science in the Age of Development Cooperation An Analytical Understanding of the Administrative System in Developed and Developing Countries. Seoul: Pakyongsa.

Im, T. (2018). Public Administration - From a Time Perspective. Seoul: Pakyongsa.

IMD. (n.d.). A brief comparison of the World Competitiveness Yearbook and the Global Competitiveness Report, Retrieved January 15, 2019, from https://www.imd.org/

In, Y. (2017). A Study on the Influence of Psychological Competitiveness in public enterprises over intrinsic job motivation. Unpublished master's thesis, Seoul National University, Seoul, Korea.

Ingraham, P. W., \& Donahue, A. K. (2000). 10 Revisited: Characterizing. Governance and performance: New perspectives, 292.

Ko, K.K \& Park, S. (2012). A Critical Review of Global Competitiveness Indices: Around the Global Competitiveness IMD and WEF Indices. Korean Journal of Public Administration. 50(3), 35 66

Leff, N. H. (1964). Economic development through bureaucratic corruption. American behavioral scientist, 8(3), 8-14.

Likert, R. (1967). The human organization: its management and values.

Longest, K. C., \& Vaisey, S. (2008). fuzzy: A program for performing qualitative comparative analyses (QCA) in Stata. Stata Journal, 8(1), 79.

Mael, F., \& Ashforth, B. E. (1992). Alumni and their alma mater: A partial test of the reformulated model of organizational identification. Journal of organizational Behavior, 13(2), 103-123.

March, J. G., \& Simon, H. A. (1958). Organizations.

Miao, Q., Newman, A., Schwarz, G., \& Xu, L. (2014). Servant leadership, trust, and the organizational commitment of public sector employees in China. Public Administration, 92(3), 727-743.

Morrison, E. W., \& Phelps, C. C. (1999). Taking charge at work: Extrarole efforts to initiate workplace change. Academy of management Journal, 42(4), 403-419.

Mudrack, P. E., Bloodgood, J. M., \& Turnley, W. H. (2012). Some ethical implications of individual competitiveness. Journal of Business Ethics, 108(3), 347-359.

Naff, K. C., \& Crum, J. (1999). Working for America: Does public service motivation make a difference?. Review of public personnel administration, 19(4), 5-16.

Neumann, O., \& Ritz, A. (2015). Public service motivation and rational choice model-ling. Public Money \& Management, 35(5), 365-370.

Newby, J. L., \& Klein, R. G. (2014). Competitiveness reconceptualized: Psychometric development of the competitiveness orientation measure as a unified measure of trait competitive-ness. The Psychological Record, 64(4), 879-895.

O'Toole, T., \& Donaldson, B. (2000). Relationship governance structures and performance. Journal of Marketing Management, 16(4), 327-341.

Paykani, T., Rafiey, H., \& Sajjadi, H. (2018). A fuzzy set qualitative comparative analysis of 131 countries: which configuration of the structural conditions can explain health bet-ter?. International journal for equity in health, 17(1), 10.

Perry, J. L., \& Wise, L. R. (1990). The motivational bases of public service. Public administration review, 50(3), 367-373. 
Podsakoff, P. M., MacKenzie, S. B., Paine, J. B., \& Bachrach, D. G. (2000). Organizational citizenship behaviors: A critical review of the theoretical and empirical literature and suggestions for future research. Journal of management, 26(3), 513-563.

Porter, M. E. (1990). The competitive advantage of nations. Competitive Intelligence Review, 1(1), 14-14.

Ragin, C. C. (1987). The comparative method: Moving beyond qualitative and quantitative methods. Berkeley: University of California.

Ragin, C. C. (2000). Fuzzy-set social science. University of Chicago Press.

Ragin, C. C. (2008). Redesigning social inquiry: Fuzzy sets and beyond, Wiley Online Library.

Ragin, C. C., Strand, S. I., \& Rubinson, C. (2008). User's guide to Fuzzy-Set. Qualitative Comparative Analysis, 87.

Sandholtz, W., \& Koetzle, W. (2000). Accounting for corruption: Economic structure, democracy, and trade. International studies quarterly, 44(1), 31-50.

Schneider, M. R., Schulze-Bentrop, C., \& Paunescu, M. (2010). Mapping the institutional capital of high-tech firms: A fuzzy-set analysis of capitalist variety and export performance. Journal of International Business Studies, 41(2), 246-266.

Schott, C., van Kleef, D. D., \& Steen, T. (2015). What does it mean and imply to be public service motivated?. The American Review of Public Administration, 45(6), 689-707.

The Worldwide Governance Indicators. (n.d.). In World Bank. Retrieved January 17, 2019 from https://globaledge.msu.edu/global-resources/resource/470

Quality of Government. (n.d.). In Quality of Government. Retrieved January 17, 2019 from

https://qog.pol.gu.se/

Trivedi, P. (2017, September 8). Meaning of 'Performance' in Government Performance Management. Retrieved from https://patimes.org/

Umphress, E. E., Bingham, J. B., \& Mitchell, M. S. (2010). Unethical behavior in the name of the company: The moderating effect of organizational identification and positive reciprocity beliefs on unethical pro-organizational behavior. Journal of applied psychology, 95(4), 769.

Vallerand, R. J., Gauvin, L. I., \& Halliwell, W. R. (1986). Negative effects of competition on children's intrinsic motivation. The Journal of Social Psychology, 126(5), 649-656.

Vandenabeele, W. (2011). Who wants to deliver public service? Do institutional antecedents of public service motivation provide an answer?. Review of public personnel administration, 31(1), 87-107.

Vigoda-Gadot, E., \& Beeri, I. (2011). Change-oriented organizational citizenship behavior in public administration: The power of leadership and the cost of organizational politics. Journal of Public Administration Research and Theory, 22(3), 573-596.

World Economic Forum. (2018). The Global Competitiveness Report. Geneva.

World Justice Project. (2018). Rule of Law Index. Washington.

\section{Appendix: Measures for Independent Variables}

\begin{tabular}{|c|c|}
\hline & Items \\
\hline \multirow[t]{5}{*}{ Competitiveness } & $\begin{array}{l}\text { When in a competition, I would like to win because that means I performed better than } \\
\text { other people. }\end{array}$ \\
\hline & $\begin{array}{l}\text { When I am competing for an award or a promotion, I mostly focus on my own } \\
\text { qualifications, rather than comparing myself with other applicants or candidates. }\end{array}$ \\
\hline & $\begin{array}{l}\text { During competitions, I tend to focus on how much better or worse the other candidates } \\
\text { performed than myself. }\end{array}$ \\
\hline & It is more important for me to achieve excellence than to win others. \\
\hline & There's a lot of competition among public servants in my country. \\
\hline
\end{tabular}


Change-oriented OCB

Public Service Motivation

Organizational
Identification

Corruption Tolerance
I try to change work processes to increase efficiency.

I try to make suggestions to improve daily operations of the organization.

I try to fix unnecessary or faulty procedures.

I try to introduce new processes to increase organizational effectiveness.

I feel very responsible for the society that I belong to.

I consider public service as my civic duty.

I think public service is more meaningful way of vocation than pursuing my own selfinterest.

I willingly take my own losses to help others.

I think social contribution is more important than personal achievement.

When somebody criticizes my department, it feels like a personal insult (or, I feel bad).

My department's successes are equivalent to my own successes.

Working in my department helps me understand who I am.

It is acceptable that a central government official gives a job to someone from his family who does not have adequate qualifications.

It is acceptable that a central government official demands a favor or an additional payment for some service that is part of his job.

It is acceptable that a central government official decides to locate a development project in an area where his friends and supporters live. 